\section{Changing the Rules of the Game: The Problem of Surrogate Angiographic Outcomes in the Evaluation of Aneurysm Treatments}

\author{
(D)T.E. Darsaut, (D) R. Chapot, and (D). Raymond
}

$\mathrm{S}$ urrogate outcomes (indicators or signs used in place of the true clinical outcome measure) are often used in the evaluation of neurovascular treatments, but there are many pitfalls. ${ }^{1}$ The various ways surrogate angiographic outcomes are handled in our literature can be sources of confusion, particularly when new endovascular devices are introduced or when attempts are made to compare the results of different treatments.

One danger in focusing on a surrogate measure is losing sight of the goal of therapy: a good clinical outcome. In the case of aneurysm treatments, this means minimizing treatment-related morbidity and efficacy in the prevention of rupture. Angiographic outcomes are still important for at least 2 reasons. First, in clinical care, we cannot wait for ruptures to occur before we decide whether treatment was a success or a failure. Doctors need some indicator of the results of their actions so that they can, for example, offer a second treatment if need be. Second, and this is particularly true for unruptured aneurysms, the number of ruptures that occur during follow-up are few. An inordinately large number of patients followed for many years would be required for a randomized trial to show clinical outcomes are improved. A surrogate angiographic outcome measure can be obtained much sooner and can then be used to show superiority of a treatment with a smaller number of patients, provided the surrogate outcome truly predicts patients' future clinical outcomes. Surrogate angiographic outcomes are thus often used in randomized controlled trials (RCTs) that compare different endovascular devices. ${ }^{2-5}$

A famous example of the classic pitfall comes from cardiology: arrhythmias were known to cause death after myocardial infarction, and antiarrhythmic agents were found to decrease the incidence of arrhythmias, ${ }^{6}$ but they were then shown to cause more deaths! ${ }^{7}$ To avoid drawing the wrong conclusion about a treatment, clinical trials must always include hard clinical end points, and the "primary outcome" of a trial should be simple, clinical, and meaningful. ${ }^{8}$ For neurovascular treatments, the problem is that these larger trials are infrequently done.

One exception is the International Subarachnoid Aneurysm Trial (ISAT), ${ }^{9}$ which compared surgical clipping and coiling of ruptured aneurysms. The primary outcome was appropriately clinical ( $m R s ~ \geq 3$ at 1 year), but it required the enrollment of 2143 patients. Angiographic outcomes were not recorded in ISAT, but it was known that the angiographic results of coiling were not as good or as durable, as advocates of surgical clipping complained: clipping achieved complete occlusion in $90 \%$ of cases compared with $45 \%-$ $50 \%$ for endovascular treatment at best. ${ }^{10}$ The appropriate response

http://dx.doi.org/10.3174/ajnr.A6825 to that concern is that the clinical results are what count; they were better with coiling in ISAT. ${ }^{9}$ In the meantime, because complete occlusions were infrequent with coiling, we learned to accept a residual neck as "acceptable" because rebleeding was rare compared with patients with residual aneurysms. ${ }^{10}$

Now flow diverters are introduced; how can the case be made that they should be used instead of coiling? A randomized trial with a clinical outcome measure, say, to ensure the complication rate of flow diversion was not double that of coiling (ie, $5 \%$ to $10 \%$ ), would require at least 865 patients. So, we use a surrogate angiographic outcome. But because we now consider residual necks as "satisfactory" and we can obtain this result in $80 \%-90 \%$ of cases, ${ }^{11}$ even this strategy won't work: a trial of 1000-1500 patients would be necessary to show that flow diversion can improve already good results. What's left to do? Well, what was done is that the threshold for what constitutes a good angiographic outcome was changed to no longer accept residual necks; in other words, the rules of the game were changed.

With this altered definition, flow diversion can be made to look good. Consider how simple it would have been to do an RCT with success defined as "complete aneurysm occlusion": a trial of approximately 110 patients or so could have been sufficient to show that flow diversion improved complete occlusions rates from $50 \%$ to $75 \%$. With a trial this size, of course, no one would be able to properly evaluate clinical outcomes: whether the improvement in the surrogate imaging finding (from near-complete to complete occlusion) was worth the added risk of flow diversion or whether it translated into better clinical outcomes in the long run. But was this simple trial even done? The unfortunate reality is that an RCT was not required to introduce flow diverters; flow diverter complete occlusion rates were simply "compared" with historical controls. $^{12}$

The latest iteration of the changing-of-the-rules-as-you-goalong problem is to adapt the classification of angiographic results to the needs of the new device, as was recently done for the WEB device. If by design the device regularly leaves a residuum at its base, it is now proposed to consider that result akin to "complete occlusion." "Adequate occlusion" is now a broad class that subsumes complete occlusions, including "complete occlusions with opacification of the recess, in addition to neck remnants need to close. ${ }^{13,14}$ In this scheme, aneurysm necks are "acceptable" (post-ISAT), then "not acceptable" (to justify flow diversion), and then "acceptable" again (to justify WEB) (Figure). Advocates of surgical clipping especially should decry that the rules of the game keep on changing. Had complete occlusion consistently stayed the reason to choose one treatment over the other (without ever properly checking impacts on clinical outcomes as was done in ISAT), clipping would still be the treatment of choice for most aneurysm patients!

One final related pitfall should be mentioned: attempts to compare treatments are further encumbered now because devicespecific scales are used to evaluate angiographic results for each treatment. ${ }^{13,15-17}$ Using a different scale for every different treatment only ensures that the results of aneurysm treatments can no longer be compared. 


\begin{tabular}{|c|c|c|c|}
\hline Angiographic results & $\begin{array}{l}\text { Interpretation of } \\
\text { Aneurysm Neck }\end{array}$ & $\begin{array}{l}\text { Evidence of } \\
\text { Angiographic } \\
\text { Outcome }\end{array}$ & $\begin{array}{l}\text { Evidence of } \\
\text { Clinical } \\
\text { Outcome }\end{array}$ \\
\hline $\begin{array}{l}\text { Pre-ISAT: } \\
\text { Clipping better ( }>90 \% \text { complete occlusion) } \\
\text { compared with coiling ( } \sim 45 \% \text { complete occlusion) }\end{array}$ & Bad & $\begin{array}{l}\text { Historical } \\
\text { only }\end{array}$ & Unknown \\
\hline \multicolumn{4}{|l|}{ ISAT (2002) } \\
\hline $\begin{array}{l}\text { Post-ISAT: } \\
\text { Coiling not better than clipping, but } \\
\text { angiographic outcomes trumped by clinical } \\
\text { outcome results (for ruptured aneurysms only) }\end{array}$ & Acceptable & None & $\begin{array}{l}\text { Better } 1 \text { year clinical } \\
\text { outcomes with } \\
\text { coiling (ISAT) }\end{array}$ \\
\hline $\begin{array}{l}\text { Flow diversion better ( } 90 \% \text { complete occlusion) } \\
\text { compared with coiling ( } \sim 45 \% \text { complete occlusion) }\end{array}$ & Bad & $\begin{array}{l}\text { Compared } \\
\text { with historical } \\
\text { controls only }\end{array}$ & $\begin{array}{l}\text { Not powered to } \\
\text { verify clinical } \\
\text { outcomes }\end{array}$ \\
\hline WEB (new device-specific scale): & $\begin{array}{l}\text { Acceptable } \\
\text { (+ recesses, too!) }\end{array}$ & $\begin{array}{l}\text { Comparisons } \\
\text { difficult and } \\
\text { historical }\end{array}$ & $\begin{array}{l}\text { Not powered to } \\
\text { verify clinical } \\
\text { outcomes }\end{array}$ \\
\hline
\end{tabular}

FIGURE. Changing the rules of the game.

Pitfalls notwithstanding, angiographic outcomes will continue to play an important role in the evaluation of neurovascular treatments. However, clinicians must remain wary of how they can be manipulated to show treatment results in a good light.

Disclosures: Rene Chapot-UNRELATED: Consultancy: Microvention, Stryker*; Payment for Lectures Including Service on Speakers Bureaus: Balt, Medtronic, Microvention, Siemens, Stryker. ${ }^{*}$ Money paid to the institution.

\section{REFERENCES}

1. Fleming TR, DeMets DL. Surrogate end points in clinical trials: are we being misled? Ann Intern Med 1996;125:605-13 CrossRef Medline

2. McDougall CG, Johnston SC, Gholkar A, et al. Bioactive versus bare platinum coils in the treatment of intracranial aneurysms: the MAPS (Matrix and Platinum Science) trial. AJNR Am J Neuroradiol 2014;35:935-42 CrossRef Medline

3. Raymond J, Darsaut TE, Guilbert F, et al. Flow diversion in aneurysms trial: the design of the FIAT study. Interv Neuroradiol 2011;17:147-53 CrossRef Medline

4. Raymond J, Roy D, White PM, et al. A Randomized Trial Comparing Platinum and Hydrogel-coated Coils in Patients Prone to Recurrence after Endovascular Treatment (the PRET trial). Interv Neuroradiol 2008;14:73-83 CrossRef Medline

5. White PM, Lewis SC, Gholkar A, et al. Hydrogel-coated coils versus bare platinum coils for the endovascular treatment of intracranial aneurysms (HELPS): a randomised controlled trial. Lancet 2011;377:1655-62 CrossRef Medline

6. The Cardiac Arrhythmia Pilot Study. The CAPS investigators. Am J Cardiol 1986;57:91-95 CrossRef

7. Ruskin JN. The cardiac arrhythmia suppression trial (CAST). $N$ Engl J Med 1989;321:386-88 CrossRef Medline

8. Haynes BR, Sackett DL, Guyatt GH, et al. Clinical Epidemiology: How to Do Clinical Practice Research. 3rd ed. Lippincott Williams \& Wilkins; 2005
9. Molyneux A, Kerr R, Stratton I, International Subarachnoid Aneurysm Trial (ISAT) Collaborative Group, et al. International Subarachnoid Aneurysm Trial (ISAT) of neurosurgical clipping versus endovascular coiling in 2143 patients with ruptured intracranial aneurysms: a randomised trial. Lancet 2002;360:1267-74 CrossRef Medline

10. Roy D, Milot G, Raymond J. Endovascular treatment of unruptured aneurysms. Stroke 2001;32:1998-2004 CrossRef Medline

11. Raymond J, Guilbert F, Weill A, et al. Long-term angiographic recurrences after selective endovascular treatment of aneurysms with detachable coils. Stroke 2003;34:1398-1403 CrossRef Medline

12. Becske T, Kallmes DF, Saatci I, et al. Pipeline for uncoilable or failed aneurysms: results from a multicenter clinical trial. Radiology 2013;267:858-68 CrossRef Medline

13. Lubicz B, Klisch J, Gauvrit JY, et al. WEB-DL endovascular treatment of wide-neck bifurcation aneurysms: short- and midterm results in a European study. AJNR Am J Neuroradiol 2014;35:432-38 CrossRef Medline

14. Pierot L, Szikora I, Barreau X, et al. Aneurysm treatment with WEB in the cumulative population of two prospective, multicenter series: 3-year follow-up. J Neurointerv Surg 2020 Jun 12 [Epub ahead of print] CrossRef Medline

15. Cekirge HS, Saatci I. A new aneurysm occlusion classification after the impact of flow modification. AJNR Am J Neuroradiol 2016;37:1924 CrossRef Medline

16. Kotowski M, Farzin B, Fahed R, et al. Residual cerebral aneurysms after microsurgical clipping: a new scale, an agreement study, and a systematic review of the literature. World Neurosurg 2019;121: e302-21 CrossRef Medline

17. O'Kelly CJ, Krings T, Fiorella D, et al. A novel grading scale for the angiographic assessment of intracranial aneurysms treated using flow diverting stents. Interv Neuroradiol 2010;16:133-37 CrossRef Medline 